\title{
Historical Roots of Czech Sign Language the first half of the 19th century
}

\section{Lenka Okrouhlíková}

\begin{abstract}
The roots of Czech Sign Language, one of the oldest European sign languages, are closely associated with the establishment of the Institute for the Deaf and Dumb in Prague in 1786. Since then, some information on visual-manual communication of the deaf has emerged in the literature focused on deaf education. The authors of these texts were predominantly educators working in institutes for deaf children; most of them commonly encountered sign language and often had some knowledge of it. Although these texts are non-linguistic, they serve as a rich source of information about the origin and development of sign language - the mother tongue of the deaf. The deaf were seen as predestined to create a nearly universal language based on natural gestures when interacting with their hearing surroundings. This simple homesign was further developed in schools. Based on the convention established between teachers and pupils, the sign language was constantly evolving and transforming, new signs were emerging, and signs for concrete as well as abstract concepts were created. Thus, Czech Sign Language emerged and was passed on to future generations of pupils of the deaf institutes. 19th century texts provide information about how the signs were formed and what they looked like.

In the present text, we focus on texts and especially dictionaries from the first half of the 19th century. Probably the oldest and most extensive historical source of Czech signs is the glossary with written sign descriptions published in 1834 by Johann Mücke.
\end{abstract}


Other important sources include books by Czech natives Franz Hermann Czech (1836) and Hieronymus Anton Jarisch (1851), containing pictures, as well as written descriptions of signs. The texts mentioned above are written in German. Czech texts do not begin to appear until the second half of the 19th century. All texts give us a naive reflection of the origin and development of sign language. However, the facts found in them were forgotten during the 20th century, when Czech Sign Language was suppressed. The texts have been long neglected by Czech educators and, later, linguists. Here, we report on our research in school archives and libraries and mention the most important of them and bring a short synthesis of their contents.

Key words: Czech Sign Language, dictionary, emergence of sign language, history, signs.

\section{Historické kořeny českého znakového jazyka: První polovina 19. století}

\section{Abstrakt}

Historické kořeny českého znakového jazyka, jednoho z nejstarších evropských znakových jazyků, jsou úzce spjaty se založením Ústavu pro hluchoněmé v Praze v roce 1786. V návaznosti na to se informace o vizuálněmotorické komunikaci neslyšících začínají objevovat v literatuře zaměřené na vzdělávání neslyšících. Autory těchto textů byli převážné pedagogové pracující ve školách pro neslyšící, kteří ve většině případů znakový jazyk sami ovládali. Ačkoliv se nejedná o jazykovědné texty, jsou bohatým zdrojem informací o vzniku a vývoji jazyka, jež byl považován za mateřský jazyk neslyšících. Neslyšící si v komunikaci se svým slyšícím okolím vytvářeli téměř univerzální jazyk založený na přirozených gestech. Tyto jednoduché domácí znaky se pak dále rozvíjely ve školách na základě konvence mezi učiteli a žáky. Znakový jazyk se zde neustále vyvíjel a transformoval, vznikaly nové znaky pro konkréta i abstrakta. Tak postupně vykrystalizoval český znakový jazyk a předával se dále z generace na generaci. Texty z 19. století přinášejí informace o tom, jakým způsobem se znaky tvořily a jaká byla jejich forma.

Tento článek se zaměřuje zejména na německy psané texty pocházející z první poloviny 19. století, které obsahují slovní popisy či obrázky znaků, jež byly s velkou pravděpodobností užívány na území Čech. Jedná se zejména o slovníček slovních popisů znaků od Johanna Mückeho (1834), dále pak o výpravnou knihu o vzdělávání neslyšících, obsahující mj. obrázky znaků od Franze Hermanna Czecha (1836) a konečně první rozsáhlý obrázkový slovník znaků od Hieronyma Antona Jarische (1851). Česky psané texty se začínají objevovat až ve druhé polovině 19. století. Zde přinášíme krátkou syntézu obsahu těchto textů, jež byly ve 20. století, kdy byl český znakový jazyk zcela 
zatlačen do pozadí a nebyl předmětem zájmů pedagogů ani lingvistů, zapomenuty ve školních archivech a knihovnách.

Klíčová slova: český znakový jazyk, historie, slovník, vznik znakového jazyka, znaky.

DOI: $10.5507 /$ epd.2021.018

\section{Introduction}

The emergence of Czech Sign Language ${ }^{1}$ was closely associated with the establishment of the first Institute for the Deaf and Dumb² in Prague in 1786. Following the decision of Emperor Joseph II, the institute was modelled on the Vienna Institute which had been founded in 1779. Therefore, the education in the Czech institute was inspired by the French school ${ }^{3}$ and especially the Viennese school and their manual methods. ${ }^{4}$ Importantly, signs were used in all of these schools. But later the original Prague method using sign language was created, and Czech Sign Language evolved naturally and more or less independently (cf. Kmoch, 1886; Malý, 1897; Krause, 1933). The Prague method was highly influential throughout the Austrian Empire ${ }^{5}$ and mutual interference and lively contacts between Vienna and Prague can be assumed. Consequently, more detailed information on the visual-manual communication (sign language) of the deaf can be found in the literature focused on deaf education. The authors of these texts

1 Czech Sign Language is a language used by the Deaf community living in the Czech Republic (for more details see Filippová \& Hudáková, 2016).

2 Deaf and Dumb or Deaf-mute (hluchoněmý) were historically used terms for deaf people, used in official titles, names and texts. In this text we use the neutral term deaf. The visual-manual deaf communication system has been called diversely (cf. Okrouhlíková, 2015). we use the term sign language as a neutral term in this text.

3 The French sign language and the French method of education had a great impact throughout Europe (see Bonnal-Vergès 2005, p. 67-104). The first headmaster of the institute in Vienna, Friedrich Stork, was a disciple of abbé de l'Épée.

4 Karel Berger (1743-1806), the first headmaster of the Prague Institute (1786-1796) and also the first teacher of the deaf in Bohemia, was a disciple of Friedrich Stork. Berger used signs in his class, but he did not publish anything about his methods. Kmoch (1886, p. 31-32) briefly describes which signs Berger used in teaching and how they were formed; for example, the sign CRY was showed as follows: "eyes and forehead withdrew, cheeks hung and mouth slightly aslant open, the index fingers slide down from the eyes to the cheeks to indicate how tears run down". For some time, the institute was without a headmaster, only teachers worked there. Two of them František Guba and Josef Shmied then taught at the institute in Vienna (cf. Kmoch, 1886; Fischbach, 1832).

5 The territory of Bohemia was part of these territorial units: 1526-1804 Habsburg Monarchy, 1804-1867 Austrian Empire, 1867-1918 Austria-Hungary. 
re predominantly educators (such as teachers, headmasters) working in institutes for deaf children. ${ }^{6}$

\section{Johann Mücke - first glossary of Czech signs}

At first, classes at the Prague Institute were taught in German only. The Czech department was not opened until 1836 (Kmoch, 1886, p. 57). The first document dealing with Czech Sign Language is in German, written by Johann Mücke (1770-1840), the second headmaster of the Prague Institute (1820-1840). Mücke studied the then contemporary books about the upbringing and education of the deaf, corresponded with experts and tried to apply the acquired experience in teaching. In 1834, he published the book Unterrichte der Taubstummen in der Lautsprache nebst einigen Bemerkungen über die Geberdenzeichen der Taubstummen. ${ }^{7}$ In this book, Mücke gives teachers and clerics guidance on how to teach those deaf children who could not be admitted to a deaf institution. The book, dealing primarily with teaching speaking and writing, has an appendix that includes a brief discourse about sign language (Geberdensprache) and a glossary of signs (Geberdenzeichen).

Mücke considers sign language to be a natural language for the deaf; as such, it is used as a primary means of communication between the teacher and new coming pupils. To communicate with pupils more efficiently, he advises the teachers to adopt the signs the pupils come to school with. Thus, the constantly evolving language was being further developed and re-shaped thanks to the exchange between the teacher and the pupils. Subsequently, pupils that were new to the school adopted these new signs; and thus the language was expanded. (Mücke, 1834, p. 91-93)

Mücke (1834, p. 92-93) suggested that the teacher must learn to label objects using their typical features and characteristics. Initially, it was a pantomime that, over time, confined itself to one or two characteristic features of the given object, which ended up being used as a sign, which made it possible to distinguish objects from one another. According to Mücke (1834, p. 93), the deaf designate objects on the basis of their form, shape, appearance, size or colour, the way they are created or used, some by their parts, or by where they occur.

Mücke encloses a glossary of signs which were used in the Prague Institute (1834, p. 93-120). The dictionary contains a total of 240 entries divided into the following thematic groups: Food and drinks; Clothing and Associated Items; Household Fittings and Dishes; Writing Requisites and Toys; Miscellaneous, frequently occurring things; Animals; People; and Verbs. Every group contains individual entries that are not ordered

6 These texts were forgotten throughout the 20th century, when the sign language was not subject of interest to educators and linguists. We tried to find these texts and present them and their content briefly in this text.

7 For more details about Mücke's life and this book cf. Okrouhlíková, 2017a. 
alphabetically. Mücke may have chosen words for the dictionary based on the items that pupils commonly encountered in their everyday lives.

The dictionary is bilingual, descriptive and unidirectional. The source language is German; the lemma is the German word - lexeme), followed by its equivalent, i.e. a written description of the particular sign in German (see Figures 1 and 2). Since many of the signs are compounds, we excerpted 23 more described signs (as a part of a compound). Thus, the dictionary contains a total of 263 written descriptions of historical signs of Czech Sign Language. The German lexemes are concrete nouns, with the exception of the last semantic group, which contains 12 verbs. Additionally, there are 17 adjectives within the compound signs group.

Figure 1

(Mücke, 1834, p. 95)
Figure 2

(Mücke, 1834, p. 113) treisformige Bewegung berferben to ber flachen finten Santo.

Rinfen. Darftellung ber gufammengebrūatten gorm ber Qinfe mit ber Spibe beb redten fleinen ffingers auf bem tinfen 3eigefinger nebft treisformiger Relbung barauf.

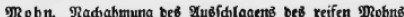
in bie linfe hohfe Şanb unb mehrmafigeb zum Daunbe führen berfelben nit ben aubgef́liagenen Mohntörnern.

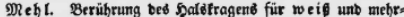
maliges शtueffreuen beß Dehls mit ben gingern beiber

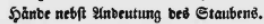

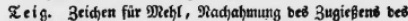
IBafferb nebft ftartem Umrübren.

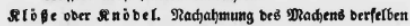

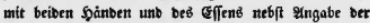
(5rö́pe.

Suden. Bezreidnung ber runben goorm über ber fladen

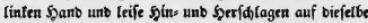
mit ber recten, Beidjen für füf, in bem man nit bem 3eigefinger bie lippen berührt unb mit einer wohtge.

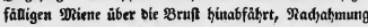

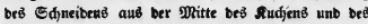
Efांent.

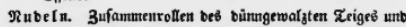
fdinelleb ङdineiben ber Zeigrolle nad, Irt ber Rubein.

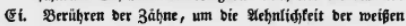

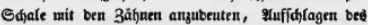

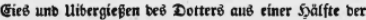
Sdjale in bie anbere.

$\mathrm{SaI}_{3}$. Beid)en für weiß, Ifuftuxfen mit bem 3eige= unb Drittelfunger auf bie Rippen, um bie Shāarfe bes Sal.

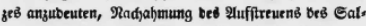
зeb mut ben brei erfiten gingern über bie Eprifen.
Einige Thicre.

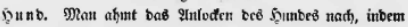

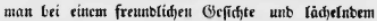

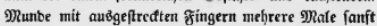
an ben Sdjentel anfdilägt, worauf man bie 5yoble an beutet.

R a B e. Wan beutet bie Iangen \$arthaare on, inbent man mit bem jufanmengehaltenen $\mathcal{L}$ aumen unb Beigefinger mehrere Male von ber Dberlippe nad beiben Geiten wegfäḩrt. Tungabe ber Şöble.

Ma a B. Man abut ben fifynellen herumfahrenben \&auf nadi, inbem man mit bem aufgeridteten Daumen unb 3eiges

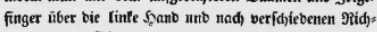
tungen herumfährt. Inbeutung ber fleinen நühe.

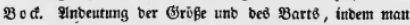

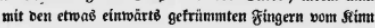

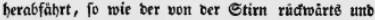

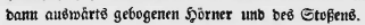

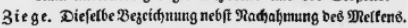

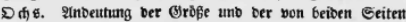

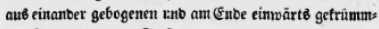
ten Ģörner unb bes Stoßens.

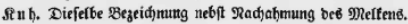
$\Re$ a fb. Inbeutung ber niebrigen Şäbe unb bCB Entgend an ber Suth, weidseo mant mit einem ginger an ben Rippen nadjab̧ut.

פfer $b$. Mant beutet bie Groje unto den herabgehenten Sopf befifelben an, intem mant mit ber franto von ber Stirn in ber Sảnge eines פferbetopfes herab unb unter bems felţen mit einer शlübeugung wieber ḩinauffährtt, worauf man bas 3ügetfaltent vor ber Bruft nadfahmut.

Efef. शan gibt bie Srößje an unb frellt bie Iangen Dhren mit beiben alfgeridfteten ફ̧änben an beiben Geiten beß Ropfee bar.

The written descriptions of the signs are very diverse; it is certainly not a precise description of all the sign's components, such as location, handshape, orientation, movement or non-manuals. There are 60 sign descriptions in which none of the above-mentioned 
components are explicitly described (in particular signs depicting mainly tools and professions, e.g. CARPENTER, BRICKLAYER, SAW, PLIERS). ${ }^{8}$ Such descriptions only inform us about what to imitate from the real world to create a sign; we learn about a sign's visual motivation, ${ }^{9}$ but we do not know what its form was. Most signs in Mücke's dictionary represent activities that are performed by a person in relation to a depicted objects (e. g. BUTTER, HANDKERCHIEF, SPOON, SHEEP). Another group of signs is characterized by the description of movement, but the handshapes are not described in any detail. In this group there are mostly signs based on the shape of the object and therefore, the trace is easily decipherable (e. g. WARDROBE, BED, BOAT, HOUSE).

The most remarkable is the group of 117 signs which attempt to describe the handshape, although the repertoire of expressions used for this purpose is quite limited and does not always give us complete information. In some descriptions, Mücke uses the names of the individual fingers: the index finger, the middle finger, the little finger and the thumb; in other descriptions, he uses only a general expression, such as the finger, or describes combinations of fingers using a phrase, such as two fingers, the nearest two fingers, or the first three fingers. We can also see expressions like the fingertips, the finger joints, and the outside of the fingers. The finger orientation is also sometimes described: downward pointing fingers, upward pointing fingers, and fingers pointing half upwards. The handshape is characterized by the position of the fingers: clenched fingers, spread fingers, open fingers, connected fingers, fingers bent in, and bent fingers. The whole handshape is then described as: flat hand, open hand, fist, clenched hand, bent hand, bent hand inward, and rounded hand. Since only the written text without graphic representation remains, we cannot say with certainty if the author truly consistently distinguished the individual handshapes and if he always described them in a uniform way, or whether some expressions are used synonymously. Due to the absence of any pictorial material, we cannot clearly assign certain handshapes to given expressions. The description of the handshapes (as well as the movement, the location, or position of the hands) appears for example in the following signs: POTATO, WATER, SCISSORS, CAT.

Given the absence or imperfect description of some components of the signs, we would probably not be able to completely reconstruct any of them. However, if we look at the descriptions through the prism of our knowledge of the lexicon of contemporary Czech Sign Language (used mainly in Bohemia), we find a clear link between the signs used in the Prague Institute in 1834 and the contemporary signs (for more details see Okrouhlíková, 2016, 2017a, 2017b, 2017c, 2018). Hence, it can be said that we have found the first, documented roots of Czech Sign Language. It is probably the oldest and also the most extensive verifiable historical source of Czech signs.

8 Sign glosses are written in capital letters.

9 For the purposes of this text, we understand motivation simply as a non-arbitrary relationship between form and meaning, ie as a visual reflection of the real world and of the properties and characteristics of objects and actions. 


\section{Franz Hermann Czech - first pictures of signs}

Another important personality for history of Czech Sign Language was Franz Hermann Czech (1788-1847). He was born in Bohemia and became a teacher at the Viennese Institute in 1818. He is the author of an extensive book on the education of the deaf from 1836: Versinnlichte Denk- und Sprachlehre mit Anwendung auf die Religions und Sittenlehre und auf das Leben. Some parts of this book (Czech, 1836, p. 107-126) deal with sign language (Geberdensprache) and sign (Geberden) formation (e.g. signs for colours, matter, rooms, time, emotions, persons, animals, body parts etc.). The formation of signs is explained by Czech (1836, p. 109) as follows:

"Every being, every thing, every state, and every action has certain characteristics which distinguish it from all other objects. These distinguishing marks of thing are either in space or in time, externally or internally, essentially or accidentally, immutable or changeable, and are perceived either by one or more senses at the same time. Through the sense of sight one perceives: the extension, the shape and form of things, their color, their use and their destiny, their position and movement, their appearance in time, their use and purpose, their placement and movement, their appearance in time, their utility or harm, the way they are created, transplanted and changed, their matter, etc. By feeling: The relation of its gravity and its temperature, the character of its surface, its density, firmness, fluidity etc. Through taste: Pleasant or unpleasant properties of things, sour, sweet, bitter, tart, salty, etc. By smell: Pleasant or unpleasant scents and types of body odour. By hearing: The sound and tones, the quality of which the deaf-mute also partly distinguishes from the effects on the feeling and judges by analogy, as: the strength and the height of the same. [...] The teacher, therefore, must direct the attention of the deaf-mute to those features which are essential to the correct representation of things. These features are characterized by outlines of the forms, by imitation of the actions, by representation of the use, etc. by the movements of the hands and other parts of the body, with or without the accompaniment of facial expressions. ${ }^{10}$

The book also contains pictures of several signs. These are probably one of the oldest picture representations of sign language signs in the world. ${ }^{11}$ However, the book is not a dictionary, and the signs are only included on some pages - tables of rich picture attachments (labelled as Tabelle).

Table 2 (see Figure 3) contains signs only: 16 pictures show the whole human figures signing and images of objects displayed next to them. The signs are not accompanied by arrows or a German equivalent or other labels. The orientation of the signer in the picture is linked with the number of hands used to articulate each sign. If the signs are one-handed, the figure is facing to the left, the dominant right hand articulates the sign and the index finger of the non-dominant left hand points to the depicted object (signs:

10 All translations in this text LO.

11 It is possible that older pictures of sings exist, we know, for example, about Die Zeichensprache der Taubstummen published in 1810 as an appendix to Leipziger Vorort-Zeitung. 
HAT, PINCE-NEZ, AUGER, SCISSORS, NUT, APPLE, PEAR). If the signs are two-handed, the figure is facing the front (or to the left), turned en face (signs: SHOE, GLOVE, MIRROR, BRUSH, BULL, DEER, DONKEY, RABBIT, CRAYFISH).

Figure 3

(Czech 1836, Tabelle 2)

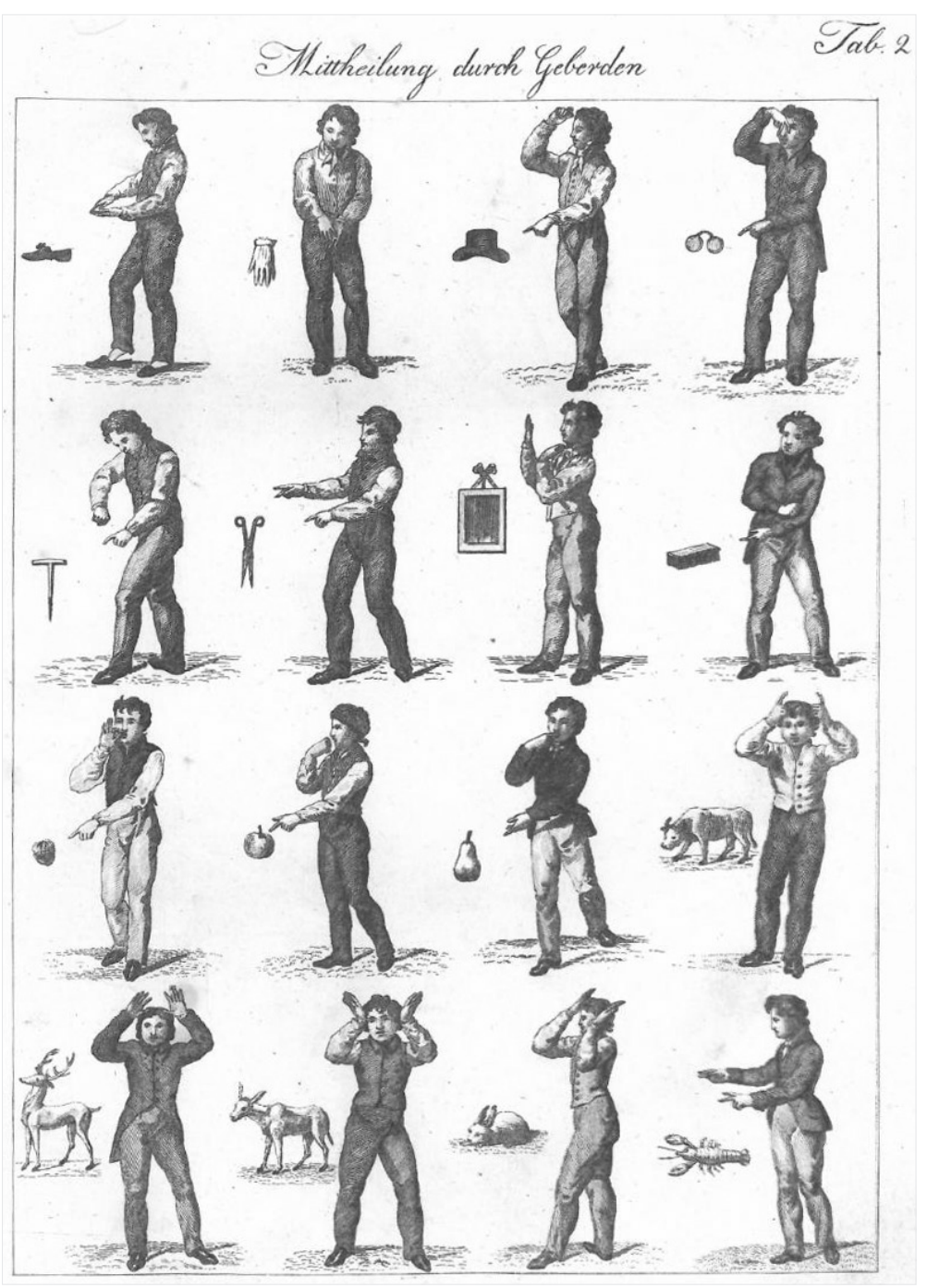


Table 14 (see Figure 4) shows signs used for personal and possessive pronouns, table 30 shows personal pronouns. Table 23 contains modal and other verbs, Table 32 (see Figure 5) shows depictions of prepositions. Other individual signs (approximately 60) can be found in the Tables 7, 8, 14, 17, 26, 27, 30, 31, 33, 34, 39, 43 and 50 (Czech, 1836). These sign images are sometimes supplemented with arrows, sometimes with equivalents (comp. Figures 4, 5).

Figure 4

(Czech, 1836, Tabelle 14)

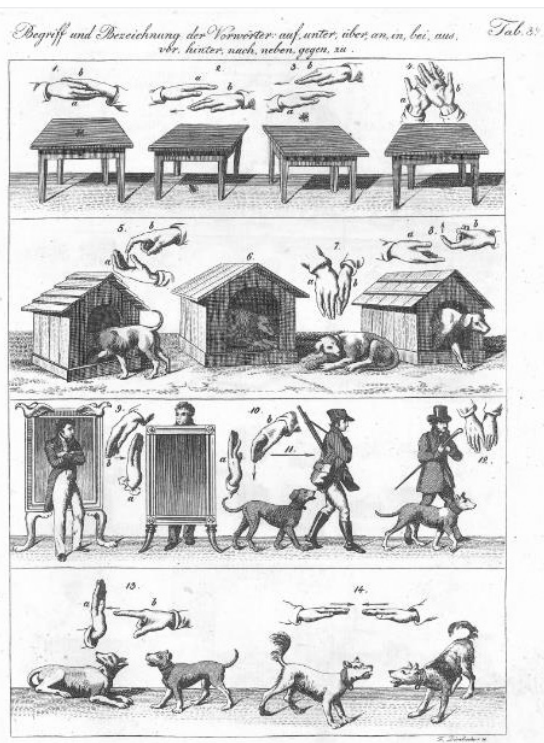

Figure 5

(Czech, 1836, Tabelle 32)

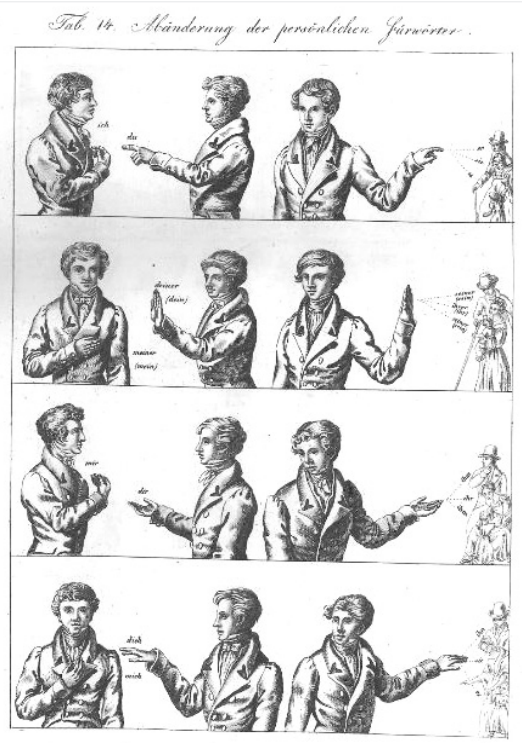

Comparing the signs that Czech captured in his book (in textual or pictorial form) with the signs described by Mücke (1834) and with the signs that are part of the lexicon of contemporary Czech Sign Language, a significant correspondence can be found. Of the 16 signs shown in Table 2 (see Figure 3), 13 have written description in Mucke's dictionary. The motivation of all 13 signs is similar (e. g. GLOVES - imitation gloves, SCISSORS - cutting, MIRROR - looking up and adjusting clothes, APPLE - round shape, DEER - antlers). Obviously, this similarity may be due to the fact that almost all of the analysed signs represent directly motivated entities, yet the signs that are motivated indirectly, such as colours (their motivation is described in the text) also match in terms of their motivation (cf. Okrouhlíková, 2016). 
Czech had either a direct or indirect (through his pupil Johann Maresch) influence on the third headmaster (1841-1865) of the Prague Institute, Wenzel Frost (1814-1865), a graduate of the priest seminary (including lectures on deaf education) in Litoměrice. In this seminary, Maresch worked as a teacher. Czech may have taught there as well (Fischer, 2010a, p. 12). ${ }^{12}$

Wenzel Frost ${ }^{13}$ is the most important personality associated with the use of sign language in education in the Prague Institute, especially in the teaching of religion. He created his own method of education, which is known as the Prague School or the Frost Method (cf. Malý, 1907, p. 72). ${ }^{14}$ The basic principle of Frost's teaching was that "[t]he natural sign speech is the mother tongue of the deaf-and-dumb, which can most quickly and surely act upon the mind and the reason of those to whom the way of imagination is closed by hearing" (Kmoch, 1886, p. 81). Frost believed that religious truths should be taught in a student's mother tongue, and that the mother tongue of the deaf is a natural sign language. Unfortunately, Frost did not leave detailed descriptions of his method or descriptions of the signs he used. Frost's approach to sign language and its formation seems to differ in many ways from the French and Viennese approaches, where signs were methodically modified and adapted to the majority language, and the finger alphabet was also used extensively. ${ }^{15}$ The fact that children from German and Czech families met at the Prague Institute probably contributed to the fact that Frost's sign language was much less "contaminated" with spoken language, and sign language was a common and barrier-free means of communication for all.

During Frost's time at the Prague Institute was a great development, as well as expansion of sign language which was gradually spread to other schools emerging in Bohemia. Many teachers both from near and far went to Frost to attend and observe his classes (Kolár, 1912, s. 213). One of the observers of Frost's classes was Hieronymus Anton Jarisch.

\section{Hieronymus Anton Jarisch - first picture dictionary}

Hieronymus Anton Jarisch (1818-1890) ${ }^{16}$ was born in Bohemia and he graduated the priest seminary in Litoměřice, as a disciple of Maresch. Jarisch spent five months in the

12 Czech's book (1836) was part of a rich library of the Prague Institute, which included mainly German-language volumes. As for French dictionaries, only the Sicard (1808) dictionary was included.

13 For more details about Frost's life see Krause, 1933.

${ }_{14}$ According to this method, it was taught in the Prague Institute until 1932, when the use of sign language was definitely banned.

15 This artificial signing has also been criticized by Czech authors (cf. Malý, 1897).

16 For more details about his life cf. his autobiography (Jarisch, 1859). 
Prague Institute in the first half of the $1840 \mathrm{~s},{ }^{17}$ where he learned sign language. He then worked as a priest, a private teacher in the Duke's family in Vienna and, sometime between 1852-1855, 15 as the main teacher at the Vienna Institute (Krause, 1933, p. 10). ${ }^{18}$

Of all Jarisch's works, ${ }^{19}$ the book Methode für den Unterricht der Taub-stummen in der Laut-sprache im rechnen und in der Religion (1851) is the most important for the history of Czech Sign Language. The book contains a brief treatise on sign language (Das Deuten oder die Zeichensprache), which is characterized as "certain hand movements, facial expressions, body positions through which we display real or imaginary objects" (Jarisch 1851, p. 40). He distinguishes three types of signing: 1. natural signing (Natürliche Deuten) created by the deaf person him/herself to communicate with the surroundings, used by the uneducated deaf; 2 . purely artificial signing (Künstliche Deuten), artificially created in school, using the finger alphabet and calques, and 3. art-regulated signing (Das durch Kunst geregelte Deuten), which is based on explanation and characteristics of things and most suitable for teaching (Jarisch, 1851, p. 41-42). The third type of signing one is described in more detail, including the explanation of the sign formation and references to the dictionary (Jarisch, 1851, p. 39-54, cf. Okrouhlíková, 2021).

The dictionary has two parts. The first part (Jarisch, 1851, p. 201-212; see Figure 6), is similar to Mücke's glossary and has the same structure. Jarisch's dictionary contains about 230 German lemmas, split into the following thematic groups:

A. Signs (Deutungen) for visible objects

a) Food and drinks

b) Fruit

c) Clothes

d) Houses (buildings)

e) Different occupations

f) Animals

g) Trees

h) Various objects

i) Objects visible in the sky

j) Spiritual beings

k) Time period

l) Abstract concepts, mental states

17 Krause $(1933$, p. 10) states it was in 1844 , and Jarisch himself wrote that he considered these five months the happiest in his life. In Prague, he learned to preach in sign language, according to the judgment of the deaf, at Frost's level (Walther, 1882, p. 265). Fischer (2010a, p. 10) states an earlier year of Jarisch's visit at the Prague Institute, around 1841-1842, which is more likely. As Jarisch himself states, he stayed at the institute at the age of twenty-four (Jarisch, 1851, p. 65)

18 For more details about Jarisch's life see his autobiography (Jarisch, 1859); Fischer, 2010a, b; Okrouhlíková, 2021.

19 Cf. https://de.wikisource.org/wiki/BLK\%C3\%96:Jarisch,_Anton_Hieronymus; https://www.deutsche-biographie.de/sfz074_00462_1.html; Fischer, 2010b. 


\section{B. Qualities}
a) Bodily
b) Colours
c) Properties of the mind
(Properties of God, Properties of Humans, Various other properties)

\section{Verbs.}

Each lemma is accompanied by a written description of the sign in German. In most cases it is a description of the sign's motivation, or what the reader should imitate or display; sometimes there is a more accurate description of the sign's components, similar to Mücke's. Some headwords refer to the second part of the dictionary (discussed below).

\section{Figure 6}

(Jarisch, 1851, p. 202-203)

\begin{tabular}{|c|c|}
\hline 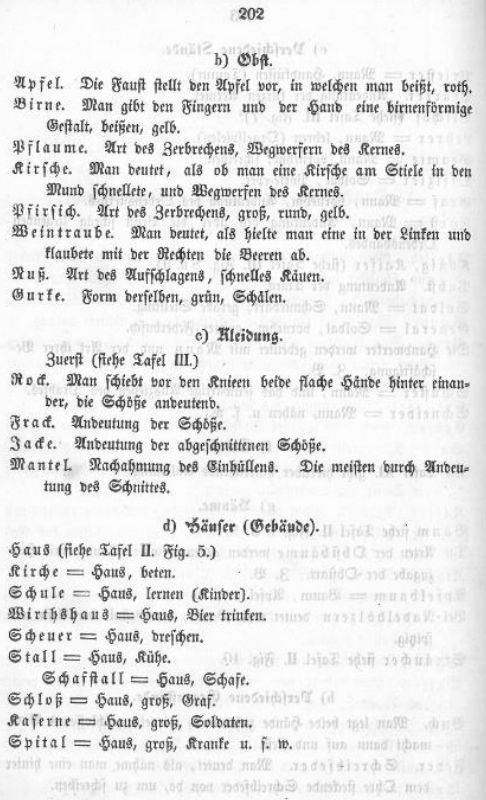 & 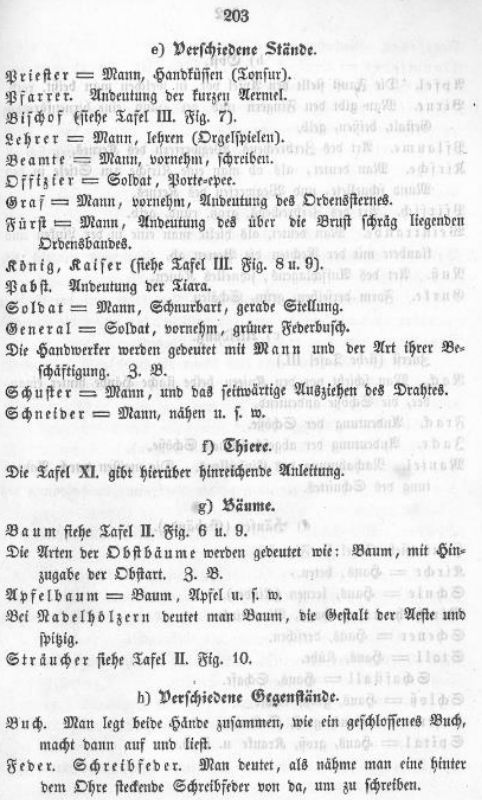 \\
\hline
\end{tabular}

The second part of the dictionary consists of 11 lithographic tables (labelled as Tafel) with 180 pictures of signs. It is probably the first extensive picture dictionary of sign 
language. ${ }^{20}$ Unlike the first part, the picture of a sign appears as the function as the lemma (the sign language being the source language). Each image is labelled Figure and is accompanied by a number: Fig. 1, Fig 2 etc. Each table (Tafel) is supplemented with a handwritten page (Erklärung der Figuren) with numbered sign equivalents or alternatively with other explanations (see Figure 7, 8, 9).

Many of these signs' images contain arrows indicating movement. The presentation of the signs varies; in some tables (No. 1, 2, 5; see Figure 7) only the hands are shown (from different perspectives, often from the perspective of the producer, possibly supplemented by arrows). In Table 3 (see Figure 8), an unusual system is used where only heads are displayed and the different arrows indicate what handshape the reader should use to articulate the sign. The other tables show the upper half of the figure (head, torso and in most cases arms); the figure is usually turned so that it is visible from the left side (exceptionally reversely); the dominant hand is, with few exceptions, the right hand (see Figure 9).

Figure 7

(Jarisch, 1851, Tafel II)
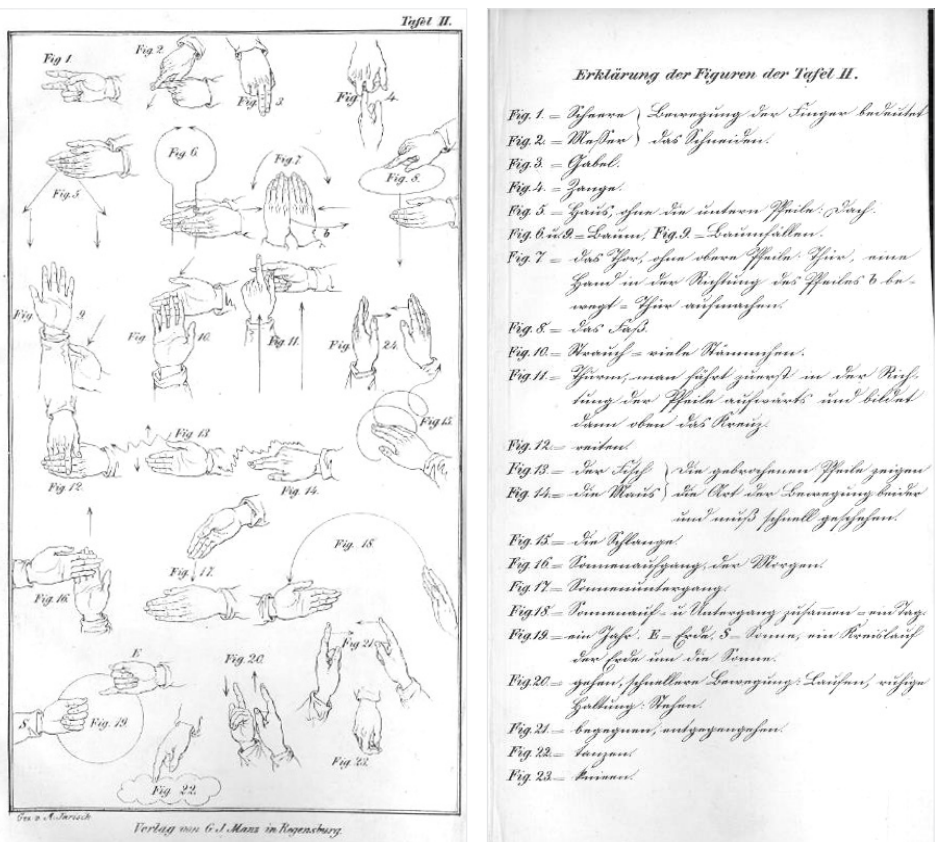

20 The first French dictionaries containing drawn signs were published a little later (cf. Brouland, 1855; Pélissier, 1856; Lambert, 1865; Laveau, 1868). 
Figure 8

(Jarisch, 1851, Tafel III)
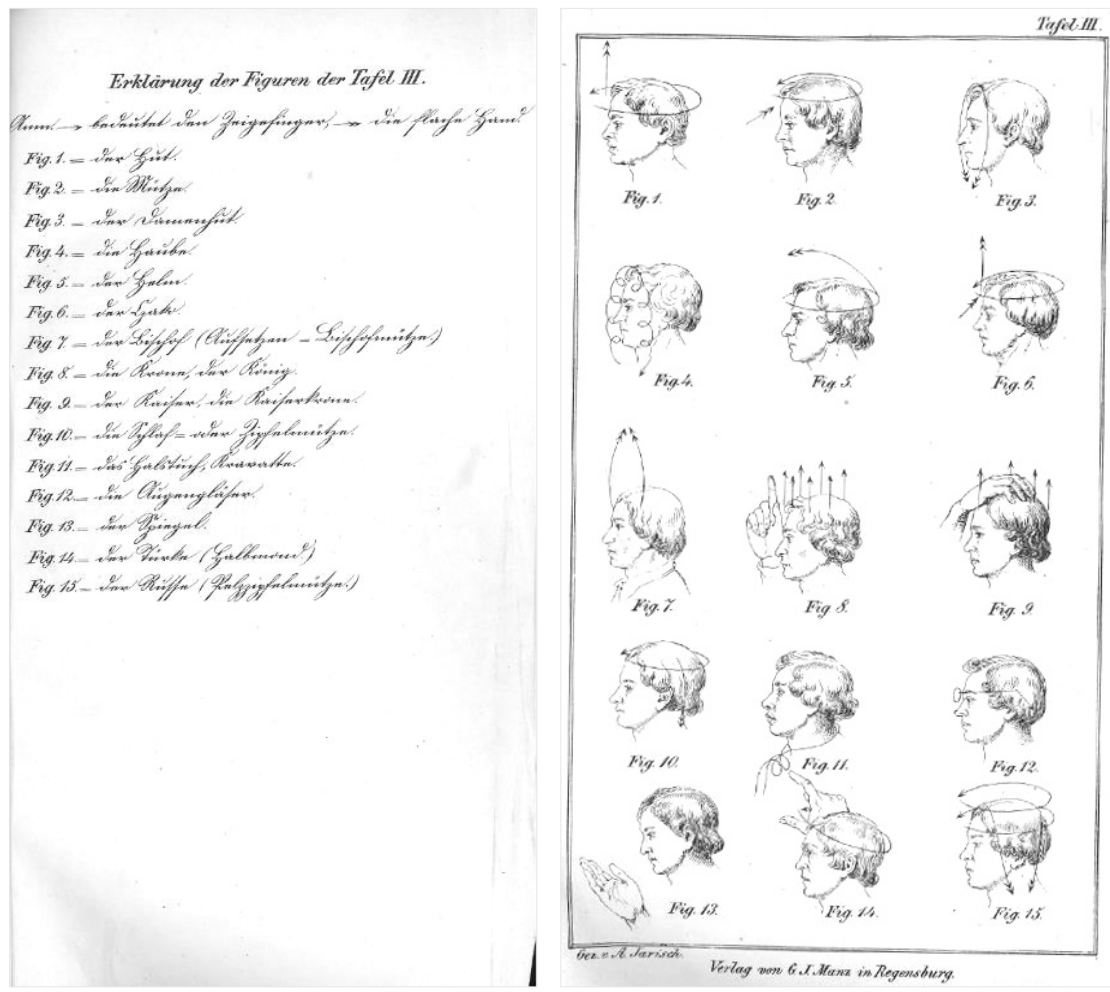
Figure 9

(Jarisch, 1851, Tafel XI)
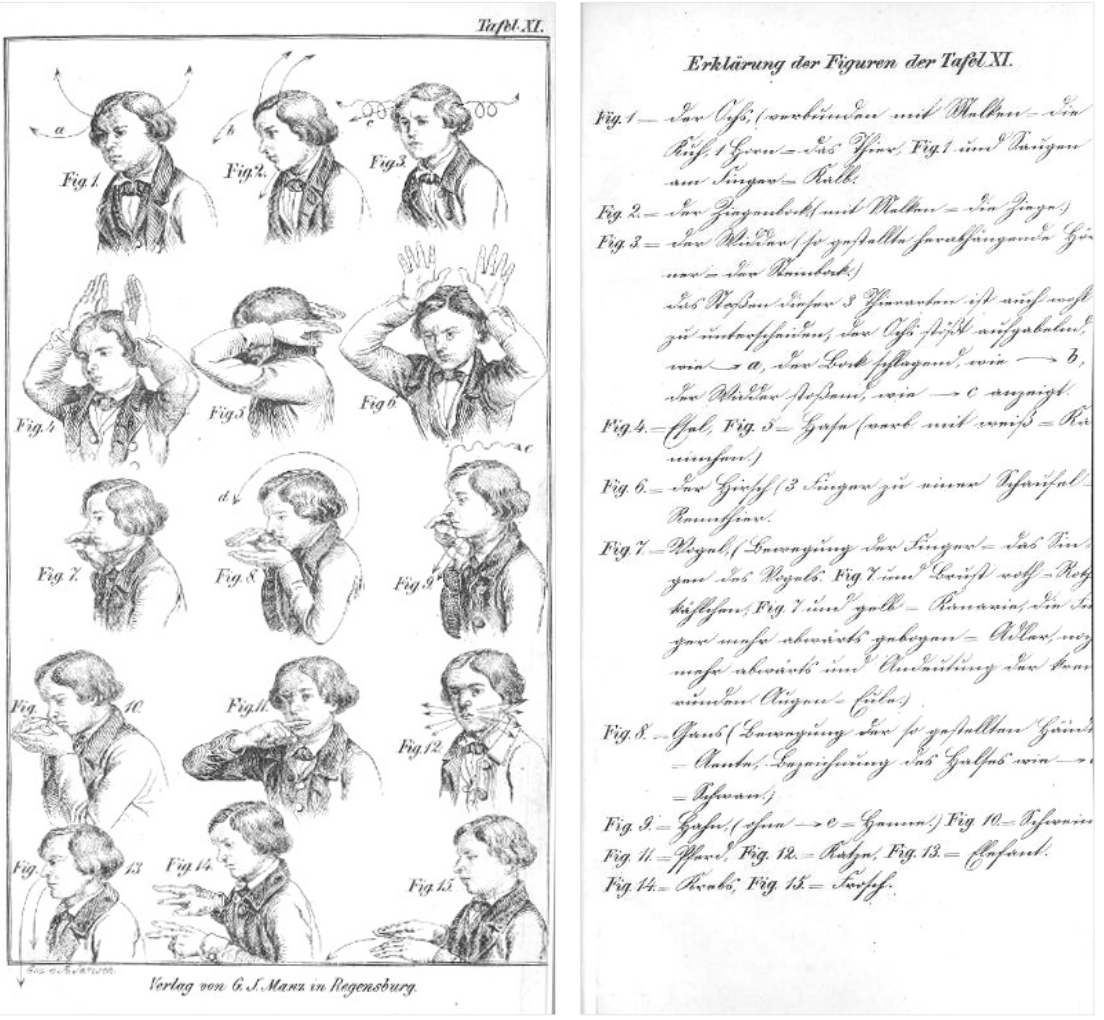

Some tables form comprehensive thematic groups, e. g. Table 3 (see Figure 8) shows signs for headgear (and related names of different persons); Table 4 shows pronouns; in Table 5 are numerals; Table 8 forms verbs; Table 10 outlines properties and Table 11 (see Figure 9) shows the signs for animals. The other tables are thematically coherent either partially - include some semantically-related signs (e. g., prepositions in Tab. 1), while other tables do not appear to be organized based on semantics or themes.

As mentioned above, Jarisch learned to use the sign language fluently from Frost at the Prague Institute for the Deaf and Dumb. He probably wrote his book during 1849-50 at a time when, after a long pause, he began to actively engage in private education of deaf girls. We therefore believe that the signs captured in the dictionary may at 
least partially represent the signs used in Prague. However, Jarisch himself states nothing about the origin of the signs, probably because he considers them almost universal.

We attempted to compare the signs in Mücke's (1834) and Jarisch's (1851) dictionary. The lists of dictionary entries overlap in 90 signs. In Jarisch's dictionary, 60 of the overlapping signs are described using written descriptions, and 30 are captured through a picture. In most cases, Jarisch's written descriptions depict only the signs' motivation and are shorter than those of Mücke; signs are composed of fewer components. An indication of the form's description, i.e. handshape, place of articulation or movement, can be found only in 19 cases. A total of 47 signs with written descriptions compared in both dictionaries can be said to have at least one identical motivation (e. g. BREAD, PEN, HEAVEN, WHITE); for 13 signs from this group, correspondence in their form can also be observed (e.g. APPLE, HARD, LIGHTNING, READ).

All 30 signs' pictures (often supplemented by a written description) observed in Jarisch's dictionary show their form and motivation. The motivation is identical to the 29 signs described by Mücke (e.g. KNIFE, HOUSE, CAT, TOWER). It means that only one of the compared signs had a different motivation.

An indication of the sign's form can be found in the written descriptions of 27 signs in Mückes' dictionary. Comparing it with the Jarischs' pictures of the signs, only four of them have a different form (in 3 cases, it is a different handshape: STAR, GOOSE, DUCK), only one sign is entirely different (it is the same sign that has a different motivation HORSE). The 23 signs are, therefore, similar (e. g. WALK, SMOKE, COCK, NAIL).

In total, the analysis of 90 compared signs showed that 76 (approx. $84 \%$ ) of them have at least one identical motivation. Of the 46 signs, where it is at least partially possible to compare the form, 36 (approx. $78 \%$ ) are similar. The degree of similarity among the compared signs is therefore relatively high. This can certainly also be influenced by the high degree of iconicity (and visual motivation) of concrete signs. However, the described sign languages can be considered related, if not identic, in this respect.

\section{Conclusion}

Czech Sign Language has a long history and is probably one of the oldest European sign languages (cf. Bakken et al. (eds.), 2015; Fischer \& Lane (eds.), 1993). As a result of belonging to the same territorial unit, as well as using similar strategies and methods of educational traditions, Czech Sign Language's historical roots and origin are closely linked to the sign language used in the Austrian countries, in particular in Vienna. However, it gradually developed as an independent language of the deaf that includes conventionalized movements of the hands, body and face. Although the language is relatively well-attested in historical documents from the first half of the 19th centuryfor example, in several glossaries and dictionaries, arguably also the first pictorial ones 
(Mücke, 1834; Czech, 1836; Jarisch, 1851) - the language is not as well-documented in the second half of the 19th century (see Okrouhlíková, 2015, 2020). Nevertheless, based on the texts of the time, we can create at least a partial image of the origin and development of Czech Sign Language (cf. Okrouhlíková, 2020).

19th century authors (Mücke, 1834; Czech, 1836; Jarisch, 1851; Staněk, 1846; Beran Novopacký 1878; Kmoch 1886; Krs 1887; Škornička, 1890, Huleš, 1891, Malý, 1897; 1907, Koláŕ, 1897) considered sign language to be the mother tongue of the deaf and present a similar view of sign language. When interacting with his/her surroundings, the deaf child was gifted, almost predestined to create an almost universal language based on natural gestures and facial expressions. Since the deaf child did not have the opportunity to move naturally from gestures to spoken language, the child's repertoire of gestures began to expand. These gestures usually only adhered to the concretes and rarely extended to the abstract level. This simple language was considered more or less universal and basically understandable even to the hearing.

Then the child entered institute for the deaf and met other deaf children. New signs emerged at school, based on the conventions co-created among the hearing or deaf teachers and deaf pupils. In the beginning, the signs were compound and descriptive (almost pantomime) and, step by step, single simpler conventional signs emerged. Signs highlighted several typical characteristics and features of the displayed reality. Thanks to these interactions, sign language was constantly evolving and transforming, and the signs for abstract concepts were also created.

We can say that Czech Sign Language was formed and constituted. Ideal conditions were created in schools, and apart from school holidays many deaf pupils gathered to spend all their time together. In addition, they were educated by teachers who did not resist using sign language either as a teaching language or as a means of teaching the majority language. Although mastering German or Czech was the desired goal of teaching, the acquisition of knowledge and the development of pupils' thinking was also important, and sign language was a welcome help.

Obviously, we do not know exactly what the entire communication system looked like, but we know roughly how it manifested outwardly and what principles the signs were formed on. The authors immediately reflected on the fact that the perception of the outside world is transmitted into the form of signs, especially the perception of movement, shape, appearance, size, activity, habitat, colour, way of use, way of production or location in space. Examples of used signs can be found in the dictionaries described above. The authors characterize the visual-manual nature of sign language's existence quite well; they claim that it is made up of the movements of the body and its parts, i.e. the most important are hands and face, namely eyes, forehead, lips, cheeks and nose.

It seems that while education in Prague was at the beginning directly or indirectly partly influenced by the French, Viennese or German methods of using signs, the Bo- 
hemian educators eventually found their own way, which had a positive influence especially on the natural formation of Czech Sign Language.

Arguably, at first, the "Viennese sign language" influenced the "sign language of Prague", so that the "Prague sign language" subsequently shaped the "Viennese sign language". Sign languages used in the territory of today's Czech Republic and Austria probably have common roots and are related to each other (cf. Bickford, 2005).

\section{References}

Bakken Jepsen, Julie, De Clerck Goedele, Lutalo-Kiingi, Sam \& William B. McGRegor (eds.). (2015). Sign languages of the world: a comparative handbook. Berlin: De Gruyter Mouton.

Beran, Novopacký Josef. (1878). O vzdělávání hluchoněmých. Osvěta: Listy pro rozhled v umění, vědě a politice. VIII(II). 588-603.

Bickford, J. Albert. (2005). The Signed Languages of Eastern Europe. SIL International and University of North Dakota.

BLKÖ: Jarisch, Anton Hieronymus [online]. [cit. 22. 05. 2021]. Dostupný z www: https://de.wikisource. org/wiki/BLK\%C3\%96:Jarisch,_Anton_Hieronymus

Bonnal-Vergès, Françoise. (2005). Sémiogenèse de la langue des signes française: Étude critique des signes de la langue des signes française attestés sur support papier depuis le XVIIle siècle et nouvelles perspectives de dictionnaires. Thèse de doctorat, Université Toulouse.

Brouland, Joséphine. (1855). Langage mimique Spécimen d'un dictionnaire des signes. Paris: mp. de I'Institution Impériale des Sourds-Muets.

Czech, Franz Herrmann. (1836). Versinnlichte Denk- und Sprachlehre mit Anwendung auf die Religions=und Sittenlehre und auf das Leben. Wien: Gedruckt und in Commission der Mechitaristen-Congregations-Buchhandlung.

Die Zeichensprache der Taubstummen. (1810). In llustrierter Familien-Freund. Beilage zur Leipziger Vorort-Zeitung, 24 (12).

Filippová Eva \& Andrea Hudáková. (2016). Czech Sign Language in contemporary Czech society. International Journal of the Sociology of Language 238, 85-103.

Fischbach, Jakob-Bernhard. (1832). Darstellung des k.k. Taubstummen-Institutes in Wien. Wien: Verlag von Anton Doll's Universitäts-Buchhandlung.

Fischer, Renate \& Harlane Lane (eds.). (1993). Looking back: a reader on the history of deaf communities and their sign languages (International Studies on Sign Language and Communication of the Deaf, 20). Hamburg: Signum.

Fischer, Renate. (2010a). Historische Gebärdensprachlexikigraphie Bei Hieronymus A. Jarisch (1851) - Teil I. Das Zeichen 24(84). 8-19.

Fischer, Renate. (2010b). Historische Gebärdensprachlexikigraphie Bei Hieronymus A. Jarisch (1851) - Teil II. Das Zeichen 24(85). 190-205.

Frost, Václav. (1855). Vollständiger Orbis Pictus für den Anschauungs-Unterricht. Praha: F. A. Credmer a Kleinbub.

Huleš, Karel. (1891). O vychovávání a vyučování hluchoněmých. České Budějovice: J. Přibyl.

Jarisch, Hieronymus Anton. (1851). Methode für den Unterricht der Taub=stummen in der Laut= sprache im rechnen und in der Religion. Regensburg: Verlag von G. Joseph Manz.

Jarich, Hieronymus Anton. (1859). Dr. Anton Hieronymus Jarisch, Weltpriester der leitmerißer Diözese, t. t. Landsdulrath, Real- und Volks-schulen-Inspector für Steiermark (Autobiographie.). In: Heindl, Johann Baptist. Gallerie berühmter Pädagogen, verdienter Schulmänner, Jugend- und 
Volksschriftsteller und Componisten aus der Gegenwart in Biographien und biographischen Skizzen. München: Jos. Ant. Finsterlin.

Jarisch, Anton Hieronymus, Indexeintrag: Deutsche Biographie [online], [cit. 22. 05. 2021]. Dostupný z www: https://www.deutsche-biographie.de/pnd117084832.html

Kmoch, Karel. (1886). Příspěvky k dějinám pražského soukromého ústavu pro vzdělání hluchoněmých na oslavu 100letého jeho trvání. Praha: Pražský soukromý ústav pro hluchoněmé.

Kolář, Josef. (1897). Návod ku předpravnému vyučování dítek hluchoněmých ve škole obecné. Vídeň: Císařský královský školní knihosklad.

Krause, Franz. (1933). Wenzel Frost, ein vergessener Geistkünder, Taubstummen- und Volkserzieher. Basel: Rudolf Geering.

Krs, Jan. Hluchoněmý a jeho vzdělání. (1887). Posel z Budče. XVIII(30, 31). 587- 596. Lambert, LouisMarie. (1865). Le langage de la physionomie et du geste. Paris: Jacques Lecoffre.

Laveau, François. (1868). Petit dictionnaire de signe illustré du Catéchisme des souds-muets. Introduction de Françoise Bonnal-Vergès. Limoges: Lambert-Lucas, 2006.

Malý, Karel. (1897). Děti hluchoněmé, nedoslýchavé, jakož i poruchami řeči stižené ve škole obecné. Praha: I. L. Kober.

Malý, Karel. (1907). Hluchoněmost. Praha: Fr. A. Urbánek.

Mücke, Johann. (1834). Anleitung zum Unterrichte der Taubstummen in der Lautsprache nebst einigen Bemerkungen über die Geberdenzeichen der Taubstummen. Prag: Druck un Papier von Gottlieb Haase Söhne.

Okrouhlíková, Lenka. (2015). Český znakový jazyk - pohled do historie. Speciální pedagogika 25(3). 278-298.

Okrouhlíková, Lenka. (2016). Znaky pro barvy včeském znakovém jazyce a jejich etymologie. Studie z aplikované lingvistiky 7(1), 55-92.

Okrouhlíková, Lenka. (2017a). Z historie českého znakového jazyka - Johann Mücke a první slovníček znaků (1834). Studie z aplikované lingvistiky, 8(1), 65-80.

Okrouhlíková, Lenka. 2017b. Znaky pro měsíce a dny v českém znakovém jazyce a jejich motivace. Speciální pedagogika, 27(1), 3-30.

Okrouhlíková, Lenka. (2017c). Zviřata ve znakových jazycích 19. století. In: Vaňková, Irena, Vodrážková Veronika \& Radka Zbořilová (eds.). Horizonty kognitivně-kulturnílingvistiky Schémata a stereotypy $v$ mluvených a znakových jazycích, 165-197. Praha: Filozofická fakulta Univerzity Karlovy.

Okrouhlíková, Lenka. (2018). Znaky pro jídlo v českém znakovém jazyce - jejich motivace a utváření v historickém kontextu. In Vaňková, Irena \& Lucie Štastná (eds.). Horizonty kognitivně-kulturní lingvistiky II Metafory, stereotypy a kulturní rozrůzněnost jazyků jako obrazů světa, 165-186. Praha: Filozofická fakulta Univerzity Karlovy.

Okrouhlíková, Lenka. (2020). Český znakový jazyk jako komunikační prostředek ve vzdělávání v 19. století. In Komunikace nejen ve speciálněpedagogickém kontextu. Sborník príspěvků z konference XIX. mezinárodní konference k problematice osob se specifickými potřebami VI. konference mladých vědeckých pracovníků. Olomouc: Univerzita Palackého v Olomouci, 95-100.

Okrouhlíková, Lenka. (2021). Z historie českého znakového jazyka - Johann Anton Jarisch a obrázkový slovník znaků (1851). [manuscript].

Pélissier, Pierre. (1865). Iconographie des signes faisant partie de L'enseignement primaire des sourdsmuets. Paris: Imprimerie et librairie de Paul Dupont.

Sicard, Roch Ambroise. (1808). Théorie des signes pour l'instruction des sourds-muets [...] Suivie d'une notice sur l'enfance de Massieu. Paris: Imprimerie de I'Institution des Sourds- Muets.

Škornička, Karel. (1890). Výchova a vyučování hluchoněmých. Ivančice: J. Vávra. Staněk, Václav. (1846). O hluchoněmotě. Časopis českého museum. XX. 748-769.

Walther, Eduard. (1882). Geschichte des Taubstummen-Bildungswesens: unter besonderer Berücksichtigung der Entwickelung des deutschen Taubstummen-Unterrichtes. Bielefeld und Leipzig: Velhagen \& Klasing, 


\section{Contact:}

Mgr. Lenka Okrouhlíková, Ph.D.

ÚJKN, FF UK, Nám. J. Palacha 2, 11638 Praha 1

e-mail: lenka.okrouhlikova@ff.cuni.cz

Lenka Okrouhlíková graduated in French and History at the Faculty of Education of the Technical University in Liberec and in Deaf Studies at the Faculty of Arts of Charles University. She completed her doctoral studies in Special Education at the Faculty of Education of Charles University. Since 2002 he has been working as an academic at the Faculty of Arts of Charles University, first at the Institute of Czech Language and Theory of Communication, and since 2013 at the Institute of Deaf Studies. She publishes works mainly in the field of notation, lexicography and history of sign languages. 